\title{
A Study on the International Legislation of Traditional Chinese Medicine: Progress and Trend
}

\author{
Herong Mao \\ School of Foreign Languages \\ Hubei University of TCM \\ Wuhan City, Hubei Province, 430065, PRC \\ trans_morning123@126.com \\ Chi Gu \\ School of Foreign Languages \\ Hubei University of TCM \\ Wuhan City, Hubei Province, 430065, PRC \\ guchihbtcm@163.com
}

\author{
Diangang Liu* \\ School of Foreign Languages \\ Hubei University of TCM \\ Wuhan City, Hubei Province, 430065, PRC \\ liudiangang@163.com \\ Ming'an Huang \\ Center for TCM Development and Research \\ Hubei University of TCM \\ Wuhan City, Hubei Province, 430065, PRC \\ minganhuang@163.com
}

\author{
Na Song \\ School of Foreign Languages \\ Hubei University of TCM \\ Wuhan City, Hubei Province, 430065, PRC
}

\begin{abstract}
In recent decades, more and more countries have commenced to highly value the development of traditional Chinese medicine (TCM) in their societies. Great progress of legislation work has been made during the rapid spread of TCM overseas. Based on the progress of TCM legislation in different countries in the world by the measurements of the start time, finish time, driving force for legislation, established management departments etc., this paper focuses on the achievement of TCM legislation internationally and the trend of its development through some cases.
\end{abstract}

Keywords-international legislation; traditional Chinese medicine; progress; trend

\section{INTRODUCTION}

As is well known, traditional Chinese medicine (TCM) has experienced a long history of development in foreign countries. In the recent years, TCM has witnessed broader prospect both at home and abroad. In China, Chinese national leaders and the general public are attaching greater importance to the development of TCM. President Xi Jinping has reiterated that, "Traditional Chinese medicine is the key to opening the treasures of Chinese civilizations”. At 2017 Belt and Road Forum for International Cooperation, Wang Guoqiang, Director-general of the State Administration of TCM then had systematically introduced the work progress of the industry of TCM under the guidance of the "Belt and Road" and the key works on the agenda about how to better serve the 'Belt and Road' Initiative in the future. According to the official statistics, TCM has already been spread to 183 countries and areas, and 16 overseas TCM centers have been established in the countries along 'Belt and Road' to date [1]. With the rapid spread of TCM abroad, more and more countries are thinking about how to put TCM legalized locally. Although there is still a long way to go during the course of international legislation of TCM, great progress has been made in quite a few countries, especially in some developed countries. In this sense, it's worth going back to the whole process of TCM legislation internationally to better perceive the progress and the trend of development in the future.

\section{The Progress of TCM Legislation Overseas}

In modern society, TCM has developed at a high speed in foreign countries. More and more foreigners begin to recognize the unique value of TCM and benefit from the effective methods and treatments of TCM. To guarantee the safety of the overseas users and regulate the medical behaviors of TCM in each country, the overseas legislation of TCM has become an irreversible trend.

Due to the differences which lie in the national conditions, cultural traditions, medical systems, etc., TCM develops at varying paces in different countries. So does the legislation of TCM in these countries. In some countries, TCM legislation was proposed very early and sound laws and regulations had been enforced years ago. In some other countries, although TCM-related legislation was discussed very late but great advance has been already achieved. However, TCM has undergone a long history of development in foreign countries, and TCM legislation has been through ups and downs in the recent years.

This research is financially supported by academic programs of Hubei provincial department of education (2014318, 15Q112 ). 
TABLE I. PROGRESS OF TCM LEGISLATION IN DIFFERENT COUNT RIES [2-4]

\begin{tabular}{|c|c|c|c|c|c|}
\hline Country & $\begin{array}{l}\text { Start } \\
\text { Time }\end{array}$ & $\begin{array}{l}\text { Finish } \\
\text { Time }\end{array}$ & Driving Force for Legislation & $\begin{array}{l}\text { Features of } \\
\text { Legislation }\end{array}$ & $\begin{array}{l}\text { Established } \\
\text { Management Department }\end{array}$ \\
\hline France & 1962 & 1987 & $\begin{array}{l}\text { French Academy of Medical } \\
\text { Sciences }\end{array}$ & $\begin{array}{l}\text { Acupuncture } \\
\text { Legislation }\end{array}$ & French Academy of Medical Sciences \\
\hline India & 1970 & 2001 & Indian Traditional Medical Center & TCM Legislation & Indian Central Council for Medicine \\
\hline Austria & 1972 & 1987 & $\begin{array}{l}\text { Austrian } \\
\text { Acupuncture } \\
\text { Association } \\
\end{array}$ & $\begin{array}{l}\text { Acupuncture } \\
\text { Legislation }\end{array}$ & Austrian Supreme Committee of Health \\
\hline $\begin{array}{l}\text { the United Arab } \\
\text { Emirates }\end{array}$ & 1978 & 2000 & $\begin{array}{l}\text { Ministry of Health of the United } \\
\text { Arab Emirates }\end{array}$ & TCM Legislation & $\begin{array}{l}\text { Alternative Medicine Office Affiliated to Min istry of } \\
\text { Health }\end{array}$ \\
\hline $\begin{array}{l}\text { Republic of } \\
\text { Korea } \\
\text { (ROC) } \\
\end{array}$ & 1980 & 2003 & $\begin{array}{l}\text { ROC’s } \\
\text { Medical Administration }\end{array}$ & TCM Legislation & $\begin{array}{l}\text { ROC's Medical Development Review Commission } \\
\text { under the } \\
\text { Ministry of Civil Affairs }\end{array}$ \\
\hline America & 1980 & 2016 & $\begin{array}{l}\text { American State } \\
\text { Governments }\end{array}$ & $\begin{array}{l}\text { Acupuncture } \\
\text { Legislation }\end{array}$ & $\begin{array}{llll}\text { American State } & \text { Departments of } & \text { Health } \\
\text { Administration } & & & \\
\end{array}$ \\
\hline Brazil & 1984 & 1988 & Acupuncture Association of Brazil & $\begin{array}{l}\text { Acupuncture } \\
\text { Legislation } \\
\end{array}$ & Brazilian Ministry of Health \\
\hline Sweden & 1984 & 2010 & $\begin{array}{l}\text { Swedish Health } \\
\text { Agency }\end{array}$ & TCM Legislation & Swedish Health Agency \\
\hline Canada & 1985 & 2004 & $\begin{array}{l}\text { Federal } \\
\text { Parliamentary of Canada }\end{array}$ & Overall Legislation & Canadian Ministry of Health \\
\hline Thailand & 1987 & 2002 & Thailand Government & TCM Legislation & Thailand Ministry of Health \\
\hline Ghana & 1988 & 2000 & Ghanaian Government & TCM Legislation & Ghanaian Food and Drug Administration \\
\hline New Zealand & 1990 & 1990 & New Zealand Government & $\begin{array}{l}\text { Acupuncture } \\
\text { Legislation } \\
\end{array}$ & New Zealand Government \\
\hline Mexico & 1990 & 2002 & $\begin{array}{lll}\begin{array}{l}\text { Acupuncture } \\
\text { Mexico }\end{array} & \text { Association of } \\
\end{array}$ & $\begin{array}{l}\text { Acupuncture } \\
\text { Legislation }\end{array}$ & Mexican Ministry of Health \\
\hline Germany & 1991 & 2007 & German Practitioners Association & $\begin{array}{l}\text { Acupuncture } \\
\text { Legislation }\end{array}$ & German Ministry of Health \\
\hline Singapore & 1992 & 2000 & Singapore's Parliament & TCM Legislation & Chinese Medicine Council of Singapore \\
\hline Myanmar & 1996 & 1996 & Ministry of Health of Myanmar & TCM Legislation & Traditional Medicine Administration \\
\hline Vietnam & 1997 & 2003 & $\begin{array}{l}\text { Vietnamese } \\
\text { Parliament }\end{array}$ & TCM Legislation & Vietnamese Traditional Medicine Administration \\
\hline Australia & 1998 & 2012 & $\begin{array}{lll}\begin{array}{l}\text { National } \\
\text { of Australia }\end{array} & \text { TCM } & \text { Association } \\
\end{array}$ & Overall Legislation & Australian Bureau of TCM \\
\hline Columbia & 1998 & 1998 & Colombian Government & $\begin{array}{l}\text { Acupuncture } \\
\text { Legislation }\end{array}$ & Colombian Government \\
\hline Switzerland & 1999 & 1999 & Swiss Confederation Government & $\begin{array}{l}\text { Acupuncture } \\
\text { Legislation }\end{array}$ & Swiss Ministry of Health and Food \\
\hline Belgium & 1999 & 1999 & Belgian Ministry of Health & $\begin{array}{l}\text { Acupuncture } \\
\text { Legislation }\end{array}$ & Belgian Ministry of Health \\
\hline Nepal & 1999 & 1999 & Nepalese Ministry of Health & TCM Legislation & $\begin{array}{l}\text { Nepalese Traditional Medicine Administration under } \\
\text { the Ministry of Health }\end{array}$ \\
\hline Italy & 1999 & 2002 & Italian Society of Physicians & $\begin{array}{l}\text { Acupuncture } \\
\text { Legislation } \\
\end{array}$ & Italian Ministry of Health \\
\hline Britain & 2000 & 2010 & TCM Group in Britain & TCM Legislation & British Ministry of Health \\
\hline South Africa & 2000 & 2004 & South African Government & $\begin{array}{l}\text { Acupuncture } \\
\text { Legislation }\end{array}$ & South African Joint Committee of Health \\
\hline Israel & 2000 & 2000 & $\begin{array}{l}\text { Israeli Chinese } \quad \text { Medicine } \\
\text { Association }\end{array}$ & $\begin{array}{l}\text { Acupuncture } \\
\text { Legislation }\end{array}$ & Israeli Ministry of Health \\
\hline Hungary & 2013 & 2015 & Hungarian Parliament & TCM Legislation & Hungarian Human Resources Department \\
\hline Chile & 2016 & 2016 & Chilean Ministry of Health & $\begin{array}{l}\text { Acupuncture } \\
\text { Legislation } \\
\end{array}$ & Chilean Ministry of Health \\
\hline Bahamas & / & l & l & $\begin{array}{l}\text { Acupuncture } \\
\text { Legislation }\end{array}$ & / \\
\hline Zimbabwe & 1 & 1 & Zimbabwean Government & TCM Legislation & Zimbabwean Government \\
\hline Namibia & / & I & Namibian Government & $\begin{array}{l}\text { TCM } \\
\text { Legislation }\end{array}$ & Namibian Government \\
\hline
\end{tabular}

As can be clearly seen from the table above, more than thirty countries in our world have passed TCM-related legislation with different focuses. TCM legislation has witnessed different development momenta at different stages of history. Among those countries, most have passed TCM legislation or acupuncture legislation respectively. However, in Australia and Canada, the overall legislation including both TCM and acupuncture have taken into effect. In the second 
place, governments of the relevant countries have been playing a dominant part in promoting TCM legislation. An easy conclusion to be made is, it is important to be valued and authorized by the mainstream society and government in order to push forward the development of TCM legislation globally.

\section{The TREND OF TCM Legislation OverseAs}

According to the chart we have mapped in our research, the international legislation work has been started as early as in the 1960s in the western world, though it had not been attached as much importance to as it is today. The number of countries that have launched TCM-related legislation has increased noticeably during 1995-2005, the total number is 17. While from 2006 to 2016, the number of countries that have successfully issued TCM-related laws and regulations is 7. A solid foundation has been laid while development momentum is not as satisfying as expected for TCM has become a hot topic all over the world in recent years. Noticeably, greater efforts should be made in the legislative work in the future.

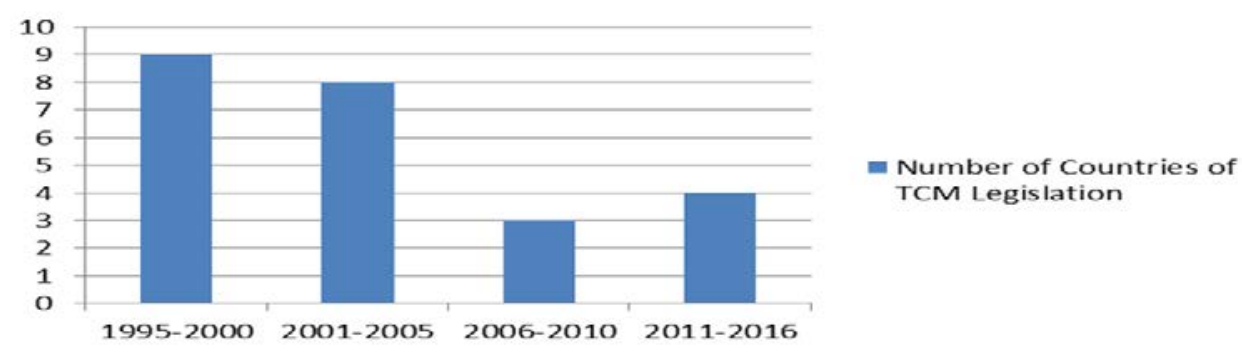

Fig. 1. Development Momentum of TCM Legislation in Different Countries

\section{CONCLUSION}

More than three hundred years ago, three Hollanders brought the Chinese acupuncture to Europe for the first time. However, TCM has not begun to rapidly develop in the western world until the 1990 s. So far, some countries have already admitted the legal position of TCM and they have set specific departments to regulate the TCM-related affairs. The countries and regions that have successfully passed legislation for acupuncture include the state of Victoria of Australia [5], Singapore, and the provinces of Quebec, Ontario, TerreNuevo of Canada, etc. The completion of legislation provides highly advantageous environment for the development of TCM in these places.

Take Singapore as an example. Here, the legislation for TCM has been being discussed since 1995 and progress was made a few years later. In 2000, the Singaporean Congress issued the Management Act of TCM Doctors. The main content of the act is the establishment of the administration council and registration institute of TCM. This act has an epoch-making significance in the history of medical management in Singapore. It does not only guarantee the legal status of TCM, but also installs a set of criterion for TCM [6]. However, it's still difficult to get most developed countries readily and entirely to accept TCM. A very urgent thing we need to do is to urge more countries to protect the development of TCM under the banner of TCM legal position in the future.

\section{ACKNOWLEDGMENTS}

This research is financially supported by academic programs of Hubei provincial department of education (2014318, 15Q112). Sincere thanks also go to colleagues from the Center for Compilation, Translation and International Communication of Jingchu TCM Literatures for their constructive suggestions in the writing of the paper.

\section{REFERENCES}

[1] Gong Xiaoqian, TCM highlights the Belt and Road Forum for International Cooperation, http://news.xinhuanet.com/health/201705/15/c_1120974007.htm, 2017-05-15. (In Chinese)

[2] Overseas Chinese TCM Groups, Development and Overview of the International TCM, TCM Newspaper, 2016-05-22, pp.1-5.( In Chinese)

[3] Xiao Shiying, Liu Tonghua, Regulations and Solutions of International Market on TCM, Beijing: Technology of TCM Press of China, 2013, pp.18-104. (In Chinese)

[4] Yan Liang, Road to Revive- the Pandect of World Traditional Medicine and Nationalization of TCM, Bejing: TCM Ancient Books Publishing House, 2012. (In Chinese)

[5] Xiaoshu Zhu, Anne-Louise Carlton, and Alan Bensoussan, Development in and Challenge for Traditional Chinese Medicine in Australia, Journal of Alternative \& Complementary Medicine, 2009, vol.15, 06, pp.685688.

[6] Sang Binsheng, Liu Xiaoting, Self- witness of the Birth of TCM Law of PRC,http://www.worldtcm.org/170325/c161150E.shtml?fro m=timeline \&isappinstalled=0, 2017-03-25.( In Chinese) 